\title{
ANALISIS PENDAPATAN USAHA TANGKAP NELAYAN DAN FAKTOR-FAKTOR YANG MEMPENGARUHINYA DI WILAYAH PESISIR PANTAI SULAWESI SELATAN ${ }^{1}$
}

\author{
Abdul Rahim \\ Program Studi Ekonomi Pembangunan \\ Konsentrasi Ekonomi Pertanian dan Agribisnis \\ Fakultas Ekonomi Universitas Negeri Makassar \\ Jln. Andi Pangeran Pettarani Kampus Gunungsari Baru Makassar, 90222 \\ Telp. 0411-868677/Hp 0815240 31697/ email : rahim_abd73@yahoo.co.id \\ Diterima 7 Maret 2011-Disetujui 3 November 2011
}

\begin{abstract}
ABSTRAK
Penelitian yang dilakukan di wilayah pesisir pantai Sulawesi Selatan bertujuan untuk menghitung besarnya perbedaan pendapatan usaha tangkap nelayan dan menganalisis faktor-faktor yang mempengaruhinya. Metode yang digunakan adalah deskriptif dan eksplanatori. Berdasarkan dimensi waktu digunakan data cross-section yang bersumber pada data primer. Responden nelayan diambil secara stratified sampling sedangkan kabupaten secara purposive sampling. Hasil penelitian menemukan bahwa pendapatan usaha tangkap nelayan perahu motor dan perahu tanpa motor di Kabupaten Jeneponto lebih besar dari nelayan Kabupaten Barru dan Sinjai. Besar-kecilnya pendapatan usaha tangkap nelayan perahu motor per trip di wilayah pesisir pantai Sulawesi Selatan dipengaruhi secara positif oleh harga minyak tanah, produktivitas, umur, dan alat tangkap rawai tetap, sedangkan secara negatif dipengaruhi oleh harga bensin, lama melaut, dan perbedaan wilayah penangkapan. Pendapatan nelayan perahu tanpa motor per trip di Sulawesi Selatan dipengaruhi secara positif oleh produktivitas jaring insang tetap dan perbedaan wilayah. Selama setahun, pendapatan nelayan perahu motor dipengaruhi secara positif oleh harga minyak tanah, dan produktivitas secara nyata positif; sedangkan secara negatif dipengaruhi oleh harga bensin, lama melaut, trip, dan perbedaan wilayah. Pendapatan nelayan perahu tanpa motor secara positif dipengaruhi oleh produktivitas, tanggungan keluarga, jaring insang tetap, dan perbedaan wilayah.
\end{abstract}

Kata Kunci: pendapatan, nelayan perahu motor dan tanpa motor

\section{Abstract : Analysis of Fisher's Fishing Income and its Various Factors Influenced in Coastal Area of South Sulawesi. By: Abdul Rahim}

Research was conducted in coastal area region of South Sulawesi which aimed to calculate the level of difference fisher's fishing income from each region of coastal area and analyze the various factors influencing it. Research method was used descriptive explanatory. A cross-section data of the primary data were used in this they. Fisher's respondent were sampled stratifically. Result of the research indicated that fishing income of motorized and non-motorized boat in regency Jeneponto bigger than Barru and Sinjai. Motorized boat fisher's fishing income per trip in coastal area of South Sulawesi positively influenced by kerosene price, productivity, age, and set long line, but negatively influenced by gasoline price, fishing day per trip, and difference of fishing areas. Non-motorized boat fisher's fishing income per trip in South influenced was Sulawesi positively by productivity of gill net and regional difference. Annual fishing income motorized boat fishers was positively influenced by kerosene price, and productivity but negatively influenced by gasoline price, fishing day per trip, number of trip, and regional difference. Income of non-motorized boat fisher was positively influenced by productivity, family size, gill net, and regional difference.

\section{Keyword : income, motorized boat fisher and non-motorized fisher}

\footnotetext{
${ }^{1}$ Bagian dari disertasi berjudul Analisis Harga Ikan Laut segar dan Pendapatan Usaha Tangkap Nelayan di Sulawesi Selatan
} 


\section{PENDAHULUAN}

Fluktuasi pendapatan dari hasil tangkapan nelayan di wilayah pesisir pantai Sulawesi Selatan (pesisir pantai barat Kabupaten Barru, pesisir pantai selatan Jeneponto, dan pantai timur Sinjai) disebabkan oleh adanya faktor musim, terutama saat musim paceklik yang biasanya ditandai dengan penurunan jumlah hasil tangkapan. Hal ini mengakibatkan fluktuasi harga sehingga berdampak pada penurunan pendapatan nelayan.

Selain itu produksi tangkapan nelayan yang didaratkan saat musim paceklik dapat pula terjadi penurunan volume produksi (berdasarkan kuantitas yang didaratkan) akibat telah dibeli pedagang di tengah laut dan didaratkan ke wilayah lain, ataupun didaratkan ke wilayah lain oleh nelayan tersebut. Hal ini pula yang membedakan pendapatan nelayan di setiap wilayah pesisir pantai yang ada di Sulawesi Selatan

Menurut Wahyono et. al (2001) dan Kusnadi (2007), pendapatan usaha tangkap nelayan sangat berbeda dengan jenis usaha lainnya, seperti pedagang atau bahkan petani. Jika pedagang dapat mengkalkulasikan keuntungan yang diperolehnya setiap bulannya, begitu pula petani dapat memprediksi hasil panennya, maka tidak demikian dengan nelayan yang kegiatannya penuh dengan ketidakpastian (uncertainty) serta bersifat spekulatif dan fluktuatif

Secara umum, pada musim paceklik produksi hasil tangkapan ikan menurun sehingga harga ikan naik karena di sisi lain permintaan atau konsumsi relatif tetap atau meningkat (Fauzi, 2005). Faktor-faktor yang mempengaruhi penghasilan nelayan dari kegiatan penangkapan adalah faktor fisik berupa kondisi lingkungan pesisir, teknologi penangkapan, lokasi penangkapan, dan modal, serta dan faktor non fisik berkaitan dengan kondisi iklim (musim), umur nelayan, pendidikan nelayan, dan pengalaman melaut (Ismail, 2004).
Menurut Mubyarto et.al (1984), tingkat kesejahteraan masyarakat pesisir umumnya menempati strata paling rendah dibanding masyarakat lainnya di darat. Bahkan nelayan termasuk paling miskin di semua negara dengan atribut "the poorest of poor" (termiskin diantara yang miskin) (Nikijuluw, 2002).

Fenomena kesejahteraan nelayan yang rendah merupakan pemasalahan yang sering terjadi, terutama pada nelayan tradisional sehingga menghambat pembangunan subsektor perikanan khususnya perikanan tangkap. Rendahnya timgkat kesejahteraan nelayan merupakan tantangan dalam mencapai tujuan pembangunan perikanan antara lain meningkatkan kesejahteraan nelayan, petani ikan, dan masyarakat pesisir lainnya (Keputusan Menteri Kelautan dan Perikanan No.18/Men/2002).

Sehubungan dengan komdisi tersebut maka diperlukan adanya analisis terhadap perbedaan pendapatan usaha tangkap nelayan perahu motor dan tanpa motor di setiap wilayah pesisir pantai Sulawesi Selatan serta faktor-faktor yang mempengaruh pendapatan usaha tangkap nelayan.

\section{METODOLOGI}

\section{Lokasi dan Waktu Penelitian}

Penelitian dilaksanakan pada bulan Juni 2008 sampai September 2008 (i) wilayah pesisir pantai barat (Kelurahan Sumpang Binangae dan Mangempang) Kabupaten Barru, kemudian (ii) wilayah pesisir pantai selatan (Kelurahan Pabiringa) Kabupaten Jeneponto, serta (iii) pesisir timur (Kelurahan Lappa) Kabupaten Sinjai.

\section{Jenis dan Sumber Data}

Jenis data yang digunakan dalam penentuan sampel adalah menggunakan data cross-section yang bersumber dari data primer yang diambil pada masing-masing kelurahan pada kabupaten sampel tahun 2008. Metode yang digunakan adalah descriptive untuk mengetahui besarnyapendapatan usaha tangkap nelayan sedangkan menganalisis 
faktor-faktor yang mempengaruhinya adalah explanatory method.

Penentuan sampel kabupaten digunakan metode purpossive sampling. Dari masing-masing sampel daerah diambil responden nelayan yang dikelompokkan berdasarkan kepemilikan armada nelayan perahu motor (motor tempel) maupun nelayan perahu tanpa motor (perahu layar atau tanpa layar) secara stratified sampling. Selain itu responden diambil secara sensus pada masing-masing kelurahan pada kabupaten terpilih dengan total nelayan sebanyak 283 jiwa terdiri nelayan perahu motor sebanyak 201 jiwa serta nelayan perahu tanpa motor sebanyak 82 jiwa.

\section{Metode Analisis Data}

Pendapatan usaha tangkap nelayan merupakan selisih antara nilai produksi tangkapan dengan biaya total operasional dengan pendekatan rumus Sharma dan Sharma (1981), Debertin (1986), dan Soekartawi (1995) maka besarnya pendapatan usaha tangkap nelayan perahu motor dirumuskan sebagai berikut :

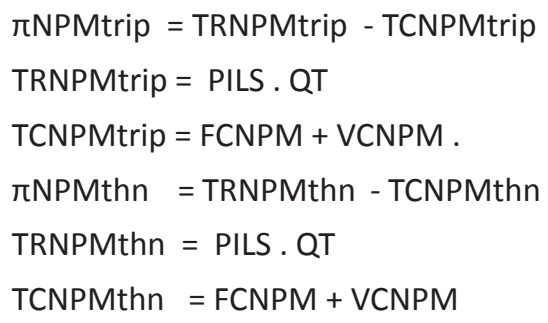

TCNPMtrip $=$ FCNPM + VCNPM .

TRNPMthn $=$ PILS. QT

TCNPMthn $=$ FCNPM + VCNPM

di mana :

rNPMtrip : Total pendapatan usaha tangkap nelayan perahu motor per trip didekati dengan keuntungan (Rp) /Motorized boat fisher's income approximaded by profit per trip (Rp).

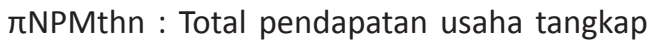
nelayan perahu motor per tahun didekati dengan keuntungan (Rp) /Annual motorized boat fisher's income approximaded by profit per trip (Rp).
TRNPMtrip: Total penerimaan nelayan perahu motor per trip (Rp) / Motorized boatfisher's revenue per trip (Rp).

TRNPMthn: Total penerimaan nelayan perahu motor per tahun (Rp) / Annual motorized boat fisher's revenue per trip (Rp).

TCNPMtrip: Total biaya penangkapan nelayan perahu motor per trip (Rp) / Motorized boat fisher's fishing cost per trip (Rp).

TCNPMthn: Total biaya penangkapan nelayan perahu motor per tahun (Rp)/ Annual motorized boat fisher's fishing cost total per trip (Rp).

PILS : Harga ikan laut segar (Rp) / Fresh fish price (Rp).

QT : Volume produksi hasil tangkapan (kg)/Volume of fish caught $(\mathrm{kg})$.

FCNPM : Biaya tetap penangkapan nelayan perahu motor (Rp) / Motorized boat fisher's fishing fixed cost per trip (Rp).

VCNPM :Biaya variabel penangkapan nelayan perahu motor (Rp)/ Motorized boat fisher's fishing variable cost per trip (Rp).

Pendapatan usaha tangkap nelayan perahu tanpa motor dirumuskan sebagai berikut :

$\pi$ NPTMtrip $=$ TRNPTMtrip - TCNPT trip $\ldots$ (7)

TRNPTMtrip = PILS . QT

TCNPTMtrip = FCNPTM + VCNPTM

$\pi$ NPTMthn $=$ TRNPTMthn - TCNPTMthn . (10)

TRNPTMthn $=$ PILS . QT

TCNPTMthn $=$ FCNPTM + VCNPTM

di mana :

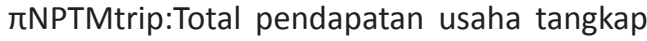
nelayan perahu tanpa motor per trip didekati dengan keuntungan (Rp) / Non-motorized boat fisher's income approximaded by profit per trip (Rp). 
rNPTMthn: Total pendapatan usaha tangkap nelayan perahu tanpa motor per tahun didekati dengan keuntungan (Rp)/ Annual nonmotorized boat fisher's income approximaded by profit (Rp).

TRNPTMtrip:Total penerimaan nelayan perahu tanpa motor per trip (Rp)/ Non-motorized boat fisher's revenue per trip (Rp)

TRNPTMthn:Total penerimaan nelayan perahu tanpa motor per tahun (Rp) / Annual non-motorized boat fisher's revenue (Rp).

TCNPMtrip: Total biaya penangkapan nelayan perahu tanpa motor per trip (Rp) /Non-motorized boat fisher's fishing cost per trip (Rp).

TCNPTMthn:Total biaya penangkapan nelayan perahu tanpa motor per tahun (Rp) / Annual non-motorized boat fisher's fishing cost per trip (Rp).

FCNPTM : Biaya tetap penangkapan nelayan perahu motor (Rp)/ Nonmotorized boat fisher's fishing fixed cost per trip (Rp).

VCNPTM :Biaya variabel penangkapan nelayan perahu motor (Rp) / Non-motorized boat fisher's fishing variable cost per trip (Rp).

Analisis faktor-faktor yang mempengaruhi pendapatan usaha tangkap nelayan digunakan pendekatan model Unit Output Price Cobb-Douglas Profit Function (UOPCDPF) (Yotopoulus dan Lau, 1971 dan Sadoulet dan Janvry, 1995) yang disusun dalam persamaan multiple linear regression berikut :

$$
\begin{aligned}
\pi \text { NPMtrip* }= & \beta_{0}+\beta_{1} \text { PBnsn* }+\beta_{2} \text { PMT }^{*}+ \\
& \beta_{3} \text { PrdvtyUTtrip }+\beta_{4} \text { AN }+\beta_{5} \\
& \text { ExMN }+\beta_{6} \text { EdN }+\beta_{7} \text { QTK }+\beta_{8} \\
& \text { Tmlutrip }+\beta_{9} \text { QATRT }+\beta_{10} \text { QATJIT } \\
& +\beta_{11} \text { PwrM }+\delta_{1} \text { DmWPB }+\delta_{2} \\
& \text { DmWPJ }+\mu_{1} \ldots . .(13)
\end{aligned}
$$

$$
\begin{aligned}
\pi \text { NPMthn* }= & \beta_{12}+\beta_{13} \text { PBnsn* }+\beta_{14} \text { PMT* } \\
& +\beta_{15} \text { PrdvtyUTthn }+\beta_{16} \text { AN }+ \\
& \beta_{17} \text { ExMN }+\beta_{18} \text { EdN }+\beta_{19} \text { QTK } \\
& +\beta_{20} \text { Tmluthn }+\beta_{21} \text { QATRT }+ \\
& \beta_{22} \text { QATIIT }+\beta_{23} \text { PWrM }+\beta_{24} \\
& \text { QTripthn }+\delta_{3} \text { DmWPB }+\delta_{4} \\
& \text { DmWPJ }+\mu_{2}
\end{aligned}
$$

Keterangan :

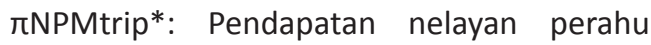
motor setiap trip yang dinormalkan dengan harga output / Normalized motorized boat fisher's income by output price per trip (IDR).

rNPMthn* : Pendapatan nelayan perahu motor setiap tahun yang dinormalkan dengan harga output (Rp)/Normalized annual motorized boat fisher's income by output price (IDR).

$\beta_{0}$ dan $\beta_{12} \quad$ : Intersep/Intercept

$\delta_{1}, \ldots, \delta_{4} \quad:$ Koefisien variabel dummy / Coefficient of dummy variable.

$\beta_{1}, \ldots, \beta_{11}$ dan

$\beta_{13}, \ldots, \beta_{24}$

: koefisien regresi variabel bebas / coefficient of regression indpendent variable.

$\delta_{1}, \ldots, \delta_{4} \quad:$ Koefisien variabel dummy / Coefficient of dummy variable.

PBnsn* : Harga bensin yang dinormalkan dengan harga output / Normalized gasoline by output price (IDR).

PMT* : Harga minyak tanah yang dinormalkan dengan harga output (Rp) / Normalized kerosene by output price (IDR).

PrdvtyUTtrip : Produktivitas usaha tangkap per trip / Productivity of fishing effort per trip (IDR) 
PrdvtyUTthn : Produktivitas usaha tangkap pertahun/Annual productivity of fishing effort (IDR)

$\begin{array}{ll}\text { AN } & \begin{array}{l}\text { : Umur nelayan (tahun) / } \\ \text { Fisher's age (year) }\end{array} \\ \text { ExMN } & \begin{array}{l}\text { : Pengalaman nelayan (tahun)/ } \\ \text { fisher's experience (year) }\end{array} \\ \text { EdN } & \begin{array}{l}\text { :Lama pendidikan formal } \\ \text { nelayan (tahun) / Fisher's } \\ \text { formal education (year) }\end{array} \\ & \text { QTK } \\ & \text { Tanggungan keluarga (jiwa)/ } \\ & \text { Family size (people) }\end{array}$

Tmlutrip : Lama melaut per trip (jam)/ Number of hour per trip (hour)

Tmluthn : Lama melaut selama setahun (tahun) / Annual number of hour (hour)

$\begin{array}{ll}\text { QATRT } & \begin{array}{l}\text { :Alat tangkap rawai tetap } \\ \text { (unit)/Long line (unit) }\end{array} \\ \text { QATIT } & \begin{array}{l}\text { :Alat tangkap jaring insang } \\ \text { tetap (unit)/ Gill net (unit) }\end{array} \\ \text { PwrM } & \begin{array}{l}\text { : Ukuran kekuatan mesin (PK)/ } \\ \text { Machine power (power knot) }\end{array} \\ \text { Qtripthn } & \begin{array}{l}\text { : Trip selama setahun (berapa } \\ \text { kali) / Annual number of trip } \\ \text { (many trip) }\end{array}\end{array}$

Dummy perbedaan wilayah penangkapan / dummy of arrest regional difference

DmWPB : 1, untuk wilayah penangkapan pesisir barat Kabupaten Barru / region of west coastal area of Barru regency

0 , untuk lainnya / to other

DmKPJ : 1, untuk penangkapan pesisir selatan Kabupaten Jeneponto/ region of west coastal area of Jeneponto regency

0 , untuk lainnya / to other

$\mu_{1}$ dan $\mu_{2} \quad$ : Kesalahan pengganggu/
Analisis faktor-faktor yang mempengaruhi pendapatan usaha tangkap nelayan perahu tanpa motor di Sulawesi Selatan dilakukan dengan menggunakan model persamaan multiple linear regression sebagai berikut : rNPTMtrip* ${ }^{*} \beta_{25}+\beta_{26}$ PMT $^{*}+\beta_{27}$ PrdvtyUTtrip $+\beta_{28} A N+\beta_{29}$ ExMN $+\beta_{30}$ EdN $+\beta_{31}$ QTK + $\beta_{32}$ Tmlutrip $+\beta_{33}$ QATRT + $\beta_{34}$ QATJIT $+\beta_{35}$ QATJPkt + $\delta_{5}$ DmKB1 $+\delta_{6} \mathrm{mKJ2}+\mu_{3}$ (15)
$\pi$ NPTMthn* $=\beta_{36}+\beta_{37}$ PMT $^{*}+\beta_{38}$ PrdvtyUTthn $+\beta_{39} A N+\beta_{40}$ ExMN $+\beta_{41}$ EdN $+\beta_{42}$ QTK $+\beta_{43}$ Tmluthn $+\beta_{44}$ QATRT $+\beta_{45}$ QATJIT $+\beta_{46}$ QATJPkt $+\beta_{47}$ QTripthn $+\delta_{7}$ DmKB1 $+\delta_{8} \mathrm{mKJ} 2+\mu_{4}$ (16)

Keterangan :

rNPTMtrip*: Pendapatan usaha tangkap nelayan perahu tanpa motor setiap trip yang dinormalkan dengan harga output / Normalized non-motorized boat fisher's income by output price per trip (IDR)

rNPTMthn*: Pendapatan usaha tangkap nelayan perahu tanpa motor setiap tahun yang dinormalkan dengan harga output/ Normalized annual motorized boat fisher's income by output price (IDR)

$\beta_{25}$ dan $\beta_{36}:$ Intersep/konstanta / Intercept/Constanta

$\beta_{26}, . ., \beta_{35}$ dan $\beta_{37}, \beta_{47}$ : Koefisien regresi variabel bebas / Coefficient of regression independent variable

QATJPkt : alat tangkap jenis jaring insang hanyut (unit) / drift 


$\delta_{5}, \ldots, \delta_{8} \quad: \begin{aligned} & \text { gill net (unit) } \\ & \begin{array}{l}\text { Koefisien variabel dummy/ } \\ \text { Coefficient of dummy } \\ \text { variable }\end{array}\end{aligned}$

$\mu_{3}$ dan $\mu_{4}$ : Kesalahan pengganggu / Disturbance error

\section{HASIL DAN PEMBAHASAN}

\section{Volume Produksi dan Harga Hasil Tangkapan}

Rata-rata hasil tangkapan tertinggi berasal dari nelayan perahu motor Kelurahan Pabiringa Kabupaten Jeneponto berupa tenggiri (Scomberomorus commersonii) dan kakap merah (Lutjantus altifrontalis) (Tabel 1). Kemudian pesisir barat nelayan perahu motor Kelurahan Sumpang Binangae Kabupaten Barru berbatasan langsung dengan Selat Makassar berupa jenis kakap merah.

Hal ini sejalan dengan penelitian Hartati dan Pralampita (1994) bahwa hasil tangkapan nelayan perahu motor tempel di Kabupaten Muna Sulawesi Tenggara berupa kakap merah dan kerapu sunu (Epinephelus tauvina) hasil tangkapan nelayan perahu motor dan perahu tanpa motor (perahu dayung) di Kelurahan Lappa Kabupaten Sinjai adalah rajungan dan kepiting bakau (Tabel 1 ).

\section{Besarnya Pendapatan Usaha Tangkap Nelayan Perahu Motor dan Perahu tanpa Motor}

Salah satu indikator untuk mengukur tingkat kesejahteraan nelayan adalah melalui tingkat pendapatan. Pendapatan usaha tangkap nelayan merupakan selisih antara penerimaan dengan biaya penangkapan yang benar-benar dikeluarkan oleh nelayan perahu motor maupun perahu tanpa motor saat musim penangkapan baik per trip maupun per tahun.

Rata-rata pendapatan usaha tangkap nelayan, baik nelayan perahu motor maupun nelayan perahu tanpa motor untuk setiap trip di ketiga kabupaten atau wilayah pesisir Sulawesi Selatan bervariasi. Tabel 2 menunjukkan pendapatan usaha tangkap nelayan perahu motor sebesar Rp 552.000/trip atau Rp 42 juta/tahun dan nelayan perahu tanpa motor Rp 193.000/ trip (Rp 16 juta/tahun). Pendapatan nelayan di wilayah pesisir pantai selatan Kabupaten Jeneponto lebih besar dari pendapatan usaha tangkap nelayan di wilayah pesisir barat Kabupaten Barru dan pesisir timur Sinjai saat musim penangkapan (Tabel 2).

Tingginya pendapatan usaha tangkap nelayan (perahu motor dan perahu tanpa motor) Kelurahan Pabiringa Kabupaten Jeneponto menunjukkan potensi sumber daya ikan di perairan Laut Flores berbatasan dengan wilayah pesisir selatan relatif lebih subur dibanding wilayah pesisir barat (Selat Makassar) dan timur (Teluk Bone). Hal tersebut terlihat dengan adanya usaha budidaya rumput laut saat musim timur.

Di samping itu, terdapat adanya pencemaran dari kepadatan bahan bakar para nelayan kapal motor berkekuatan 30-50 GT bahkan sampai 100 GT dengan alat tangkap bagan rambo dan purseine yang lebih tinggi pada perairan Selat Makassar dan Teluk Bone. Menurut Nitimulyo (2000) adanya pencemaran akan menurunkan daya dukung (carriying capacity) sehingga besarnya populasi ikan akan menurun.

\section{Faktor-faktor yang mempengaruhi Pendapatan Usaha Tangkap Nelayan Perahu Motor dan Perahu tanpa Motor}

Nilai koefisien harga bensin sebagai variable input berpengaruh negatif dan nyata secara statistik masing-masing pada tingkat $1 \%$. Hal ini berarti telah sesuai dengan teori atau nilai harapan bertanda negatif, yaitu jika terjadi peningkatan harga bensin maka akan menurunkan pendapatan usaha tangkap nelayan perahu motor baik per trip maupun per tahun.

Merujuk pada harga bensin masingmasing kabupaten sampel, nelayan perahu motor memperoleh harga bahan bakar 


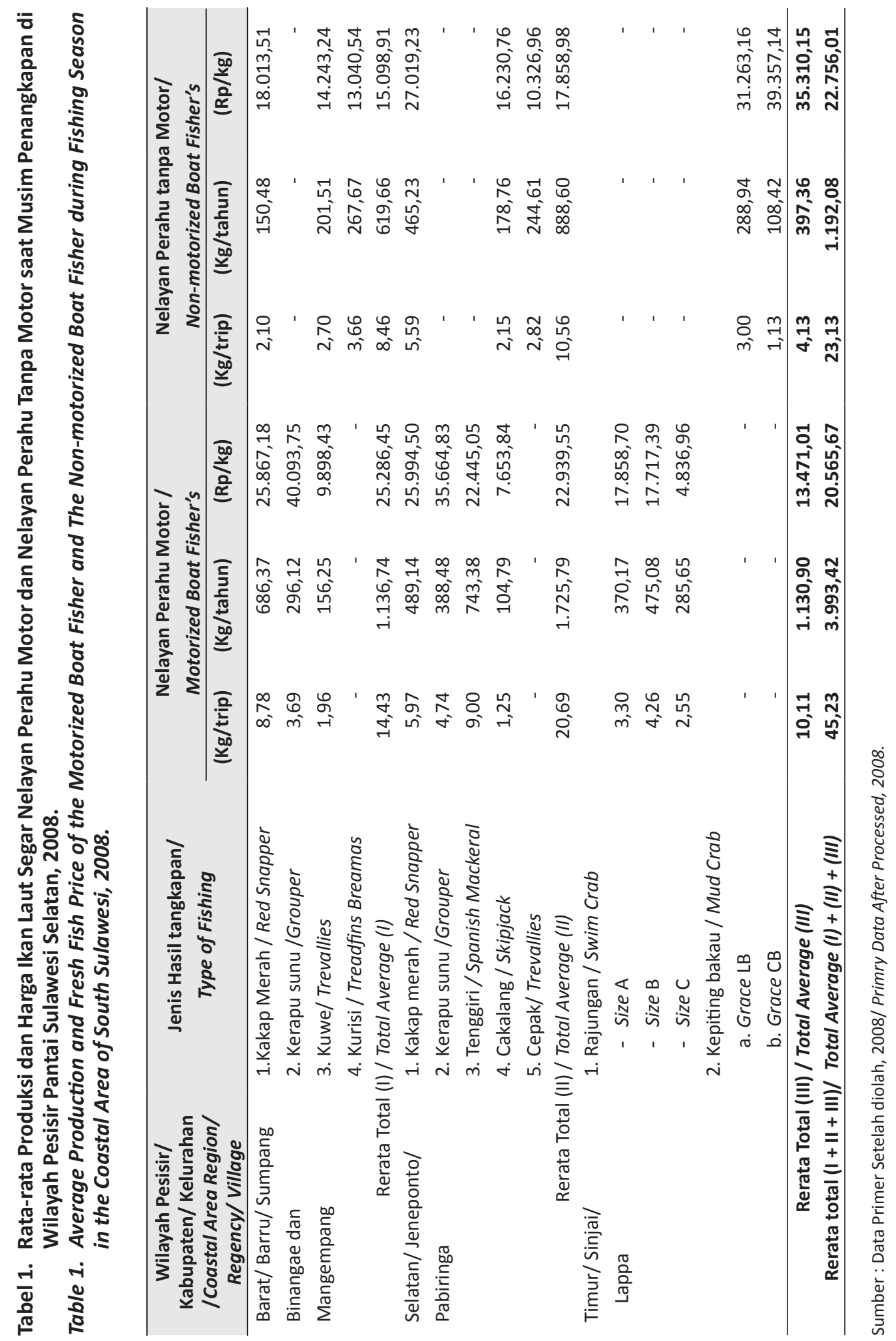




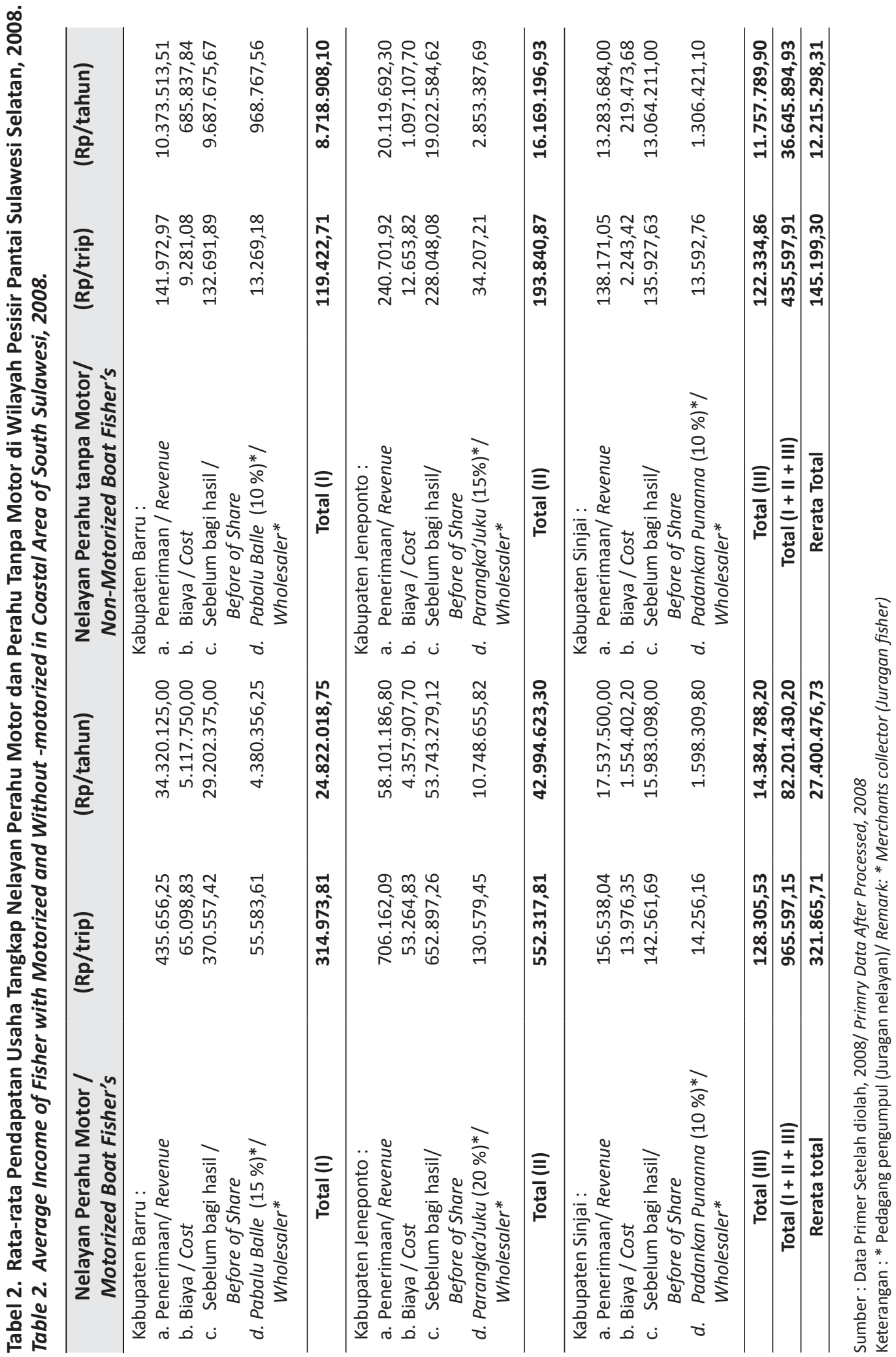


bensin dari pedagang di Kabupaten Jeneponto dan Sinjai antara Rp 6.500 s.d. Rp 7.000/liter, sedangkan Kabupaten Barru harganya sebesar Rp 6.000/liter diperoleh langsung dari SPBU di sekitar pusat pendaratan ikan.

Variabel harga bahan bakar minyak tanah berpengaruh nyata secara positif terhadap pendapatan usaha tangkap nelayan per trip dan per tahun perahu motor pada tingkat kesalahan $1 \%$. Artinya jika terjadi kenaikan harga minyak tanah, maka pendapatan usaha tangkap nelayan perahu motor per trip maupun per tahun akan meningkat pula selama musim penangkapan. Hal ini bertentangan dengan tanda harapan negatif, yaitu jika terjadi kenaikan harga minyak tanah, maka pendapatan usaha tangkap nelayan per trip maupun per tahun akan menurun. Kejadian ini berpengaruh positif terjadi karena banyaknya pemakaian minyak tanah selama melaut dua sampai tiga hari terutama nelayan perahu motor Kabupaten Barru dan Jeneponto.

Selanjutnya pengaruh positif menunjukkan adanya peningkatan nilai produktivitas dari hasil usaha tangkap akan meningkatkan pendapatan usaha tangkap nelayan perahu motor dan perahu tanpa motor pada daerah wilayah pesisir Sulawesi Selatan baik per trip maupun per tahun (lihat Tabel 3). Produktivitas usaha nelayan saat musim penangkapan sangat tergantung dari harga jual ikan masing-masing pengumpul atau juragannya (pabalu'balle, parangka'juku, dan padankan punnanna) sehingga sangat mempengaruhi perubahan pendapatan nelayan perahu motor dan perahu tanpa motor.

Umur nelayan perahu motor di wilayah pesisir pantai Sulawesi Selatan berpengaruh nyata positif pada tingkat kesalahan $10 \%$, artinya meningkatnya umur nelayan akan meningkatkan pendapatan per trip selama musim penangkapan. Hal ini bertentangan dengan tanda harapan yang negatif, yaitu jika umur nelayan bertambah, maka pendapatan usaha tangkap nelayan perahu motor menurun akibat dari menurunnya produktivitas.
Sedangkan pengalaman melaut tidak berpengaruh nyata terhadap pendapatan usaha tangkap nelayan perahu motor dan perahu tanpa motor. Hal ini dapat terjadi karena terdapat pengalaman nelayan kurang atau sama dengan 10 tahun pada ketiga wilayah pesisir pantai Sulawesi Selatan. Lain halnya variabel jumlah tanggungan keluarga berpengaruh nyata positif terhadap pendapatan usaha tangkap nelayan perahu tanpa motor pada tingkat $10 \%$, artinya dengan adanya peningkatan jumlah tanggungan nelayan, maka semakin meningkat pendapatan nelayan dari usaha tangkapnya, hal tersebut telah sesuai dengan teori dan tanda yang diharapkan, yaitu negatif.

Pengaruh positif diartikan bertambahnya tanggungan keluarga akan memotivasi nelayan perahu tanpa motor dalam mencari nafkah sebagai tulang punggung keluarga. Jumlah tanggungan tertinggi nelayan perahu tanpa motor sebanyak empat (4) jiwa dibandingkan nelayan perahu motor sampai delapan (8) jiwa. $\mathrm{Hal}$ ini berbeda dengan penelitian Harahap (2003) di perairan Kota Medan bahwa jumlah tanggungan tidak berpengaruh terhadap pendapatan usaha tangkap nelayan tradisional.

Lamanya melaut nelayan setiap trip maupun per tahun berpengaruh nyata secara negatif terhadap pendapatan usaha tangkap nelayan perahu motor pada tingkat kesalahan $1 \%$. Artinya jika nelayan perahu motor melaut dalam waktu yang lama dalam menangkap ikan, maka pendapatan usaha tangkapnya menurun. Hal ini berbeda dengan tanda positif yang diharapkan, yaitu semakin lama nelayan melaut maka pendapatan hasil tangkapan akan meningkat. Keadaan dari pengaruh negatif ini dapat saja terjadi karena jarak tangkap fishing ground lebih jauh sehingga biaya meningkat, hal ini menurunkan pendapatan nelayan. Trip selama setahun berpengaruh nyata negatif pada tingkat kesalahan $1 \%$ terhadap pendapatan usaha tangkap nelayan perahu motor, artinya semakin banyak jumlah trip nelayan 


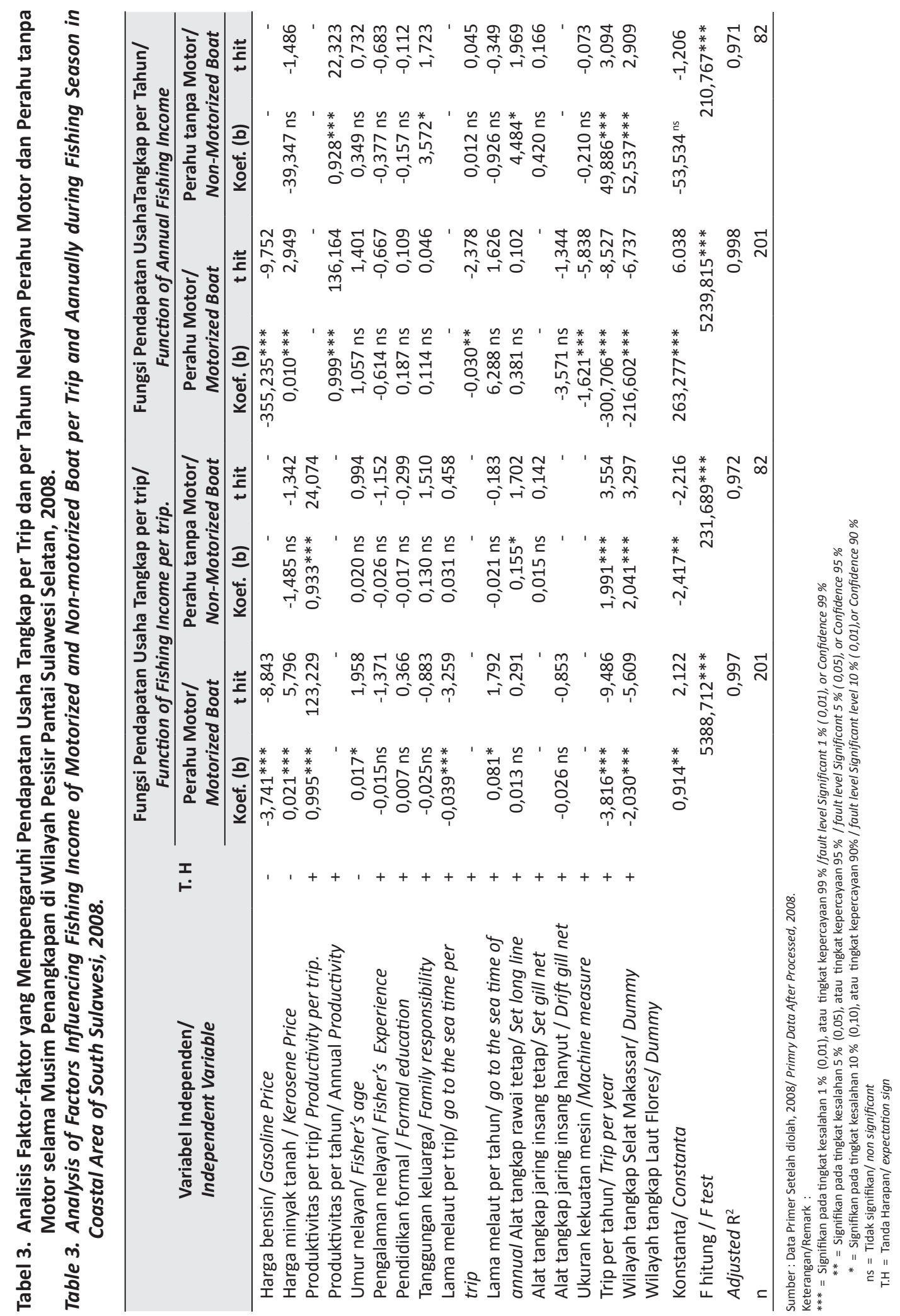


perahu motor maka pendapatan usaha dari kegiatan penangkapan semakin menurun.

Hal ini berbeda dengan tanda negatif yang diharapkan, yaitu semakin banyak trip dalam menangkap ikan maka pendapatan usaha tangkapnya akan meningkat. Jenis alat tangkap berpengaruh nyata positif terhadap pendapatan usaha tangkap per trip dan per tahun nelayan perahu motor maupun perahu tanpa motor. Pada variabel jumlah alat tangkap rawai tetap (set long line) berpengaruh nyata positif pada tingkat kesalahan $10 \%$ terhadap pendapatan usaha tangkap nelayan perahu motor per trip di Sulawesi Selatan. Hal ini telah sesuai dengan tanda yang diharapkan, jika jenis alat tangkap rawai meningkat maka pendapatan nelayan akan meningkat dari hasil tangkapan alat tersebut.

Ukuran kekuatan mesin dari nelayan perahu motor di Sulawesi Selatan juga tidak berpengaruh nyata terhadap pendapatan usaha tangkap nelayan, baik per trip maupun per tahun. Walaupun berbagai ukuran kekuatan mesin digunakan nelayan untuk mencapai jarak daerah penangkapan (fishing ground), tetapi sering nelayan menangkap pada terjadi bulan purnama sehingga tidak memperoleh hasil.

Dummy wilayah penangkapan berpengaruh nyata positif terhadap pendapatan usaha tangkap nelayan perahu tanpa motor serta pengaruh negatif terhadap pendapatan usaha tangkap nelayan perahu motor di wilayah penangkapan pada perairan Sulawesi Selatan pada tingkat kesalahan $1 \%$. Pengaruh positif telah sesuai dengan tanda harapan, yaitu pendapatan usaha tangkap nelayan perahu tanpa motor wilayah penangkapan di perairan Selat Makassar Kabupaten Barru baik per trip maupun per tahun lebih besar dari pendapatan usaha tangkap nelayan perahu tanpa motor wilayah penangkapan perairan Laut Flores Kabupaten Jeneponto dan perairan Teluk Bone Kabupaten
Sinjai. Kemudian pengaruh negatif lainnya menunjukkan pendapatan nelayan perahu motor dari wilayah penangkapan Laut Flores lebih kecil dari pendapatan nelayan dari wilayah penangkapan Selat Makassar dan Teluk Bone.

\section{KESIMPULAN DAN IMPLIKASI KEBIJAKAN}

\section{Kesimpulan}

1. Selama musim penangkapan pendapatan usaha tangkap nelayan perahu motor dan tanpa motor, baik per trip maupun per tahun di wilayah pesisir selatan Kabupaten Jeneponto lebih besar dibanding wilayah pesisir barat Barru dan pesisir timur Sinjai.

2. Besar-kecilnya pendapatan usaha tangkap nelayan perahu motor per trip di wilayah pesisir Sulawesi Selatan dipengaruhi secara positif oleh harga minyak tanah, produktivitas usaha tangkap, umur, dan alat tangkap jenis rawai tetap, kemudian secara negatif dipengaruhi oleh harga bensin, lama melaut, dan perbedaan wilayah penangkapan, sedangkan pendapatan usaha tangkap per tahun dipengaruhi secara positif oleh harga minyak tanah, dan produktivitas usaha tangkap, kemudian negatif dipengaruhi oleh harga bensin, lama melaut, trip, dan perbedaan wilayah penangkapan.

3. Pendapatan usaha tangkap nelayan perahu tanpa motor per trip di Sulawesi Selatan dipengaruhi secara positif oleh produktivitas usaha tangkap, jaring insang tetap, dan perbedaan wilayah penangkapan. Sedangkan selama setahun pendapatan usaha tangkap nelayan perahu tanpa motor dipengaruhi secara positif oleh produktivitas usaha tangkap, tanggungan keluarga, alat tangkap jaring insang tetap, dan perbedaan wilayah penangkapan. 


\section{Implikasi Kebijakan}

Produktivitas dari usaha tangkap nelayan berpengaruh nyata secara positif terhadap pendapatan usaha tangkap nelayan perahu motor dan tanpa motor telah bertentangan dengan teori atau tanda harapan. Hal tersebut terjadi karena produktivitas sangat ditentukan oleh pedagang pengumpul (juragan sendiri), untuk itu diperlukan adanya peran atau kerjasama dengan pengumpul yang menyerupai patron-klien jika programprogram pemerintah tidak terlaksana secara berkesinambungan.

Pengaruh positif antara umur dan pendapatan usaha tangkap nelayan perahu motor yang berbeda dengan tanda yang diharapkan, untuk itu diperlukan adanya adanya dana asuransi atau jaminan kesehatan terutama saat musim paceklik bagi nelayan berusia senja. Pemberian dana dapat mengacu pada sistem jaminan sosial nasional (SJSN) Undang-undang No. 40 Tahun 2004 mengenai program kesejahteraan rakyat dan Undang-undang No.6 Tahun 1974 yang merujuk dari konvensi International labour organization (ILO) No.52 Tahun 1952, juga tentang jaminan sosial dan kesejahteraan.

\section{DAFTAR PUSTAKA}

Anonimous. Kementerian Kelautan dan Perikanan Menteri Kelautan dan Perikanan Nomor 18/Men/2002. Tentang Rencana Strategis Pembangunan Kelautan Perikanan Tahun 2002-2004, Jakarta. Halaman 18

Badaruddin. 2005. Modal Sosial (Social Capital) dan Pemberdayaan komunitas nelayan, Isu-isu Kelautan (dari Kemiskinan hingga Bajak Laut), Pustaka Pelajar, Yogjakarta.

Debertin, D.L. 1986. Agricultural Production Economics, Mac Millan Publishing Company, New York.

Fauzi, A. 2005. Kebijakan Perikanan dan
Kelautan (Isu, Sintesis, dan Gagasan), Gramedia Pustaka Utama, Jakarta.

Harahap, A.S. 2003. Analisis Masalah Kemiskinan dan Tingkat Pendapatan Nelayan Tradisional di Kelurahan Nelayan Indah Kecamatan Medan Labuan Kota Medan, Tesis-S2 Program Pascasarjana, Universitas Sumatera Utara (tidak dipublikasikan).

Hartati,S.T., dan W.Pralampita. 1994. Dugaan Potensi dan Status Pemanfaatan Sumberdaya Ikan Kerapu (Grouper) dan Kakap Merah/Bambangan (Red Snapper) di Perairan Kabupaten Muna Sulawesi Tenggara, Jurnal Perikanan Laut No. 94 Tahun 1994. Jakarta.

Ismail, Z. 2004. Faktor-faktor yang mempengaruhi Penghasilan dan Pola Konsumsi Nelayan, Dampak Kerusakan Lingkungan Pesisir terhadap Kondisi Sosial Ekonomi Nelayan, Jakarta. Kusnadi. 2007. Jaminan Sosial Nelayan, Pelangi Aksara, Yogjakarta.

Mubyarto, L. Sutrisno, M. Dove. 1984. Nelayan dan Kemiskinan, Studi Ekonomi Antrologi di Dua Ekonomi desa, Rajawali, Jakarta.

Nikijuluw, V.P.H. 2002. Rezim Pengelolaan Sumberdaya Perikanan. P3R, Jakarta.

Nitimulyo, H.K. 2000. Pengeloaan Sumberdaya Ikan Berkelanjutan untuk Menunjang Pembangunan Nasional pada Pidato Pengukuhan Guru Besar Fakultas Pertanian Universitas Gadjah Mada 18 Maret 2000, Kumpulan Pidato Pengukuhan Guru Besar IImu-ilmu Pertanian, Universitas Gadjah Mada, Jogjakarta.

Sadoulet, E. dan A. de Janvry. 1995. Quantitative Development Policy Analysis, Hopskins University Press, Baltimore and London.

Soekartawi. 1995. Analisis Usahatani. UI Press, Jakarta.

Sharma, A.N. dan V.K. Sharma. 1981. Elements of Farm Management, Prentice Hall of India Private, New Delh. 
Wahyono, A.., I.G.P.Antariksa, M., Imron., R. Indrawasih, dan Sudiyono. 2001. Pemberdayaan Masyarakat Nelayan. Media Pressindo, Jogjakarta.
Yotopoulus, P.A., dan J.L. Lau. 1971. Test for Relative Economics Efficiency: Same Further Result, Journal The American Economics Review, New York. 